\title{
MODEL PEMBELAJARAN STUDENT TEAM ACHIEVEMENT DIVISION (STAD) DAN MODEL PEMBELAJARAN TEAMS GAMES TOURNAMENT (TGT): DAMPAK TERHADAP HASILBELAJAR FISIKA
}

\author{
Tri Ariani ${ }^{1,}$ Duwi Agustini $^{2}$ \\ Program Studi Pendidikan Fisika STKIP-PGRI Lubuklinggau ${ }^{1,2}$ \\ triariani.ta@gmail.com ${ }^{1}$ \\ Submit, 02-06-2018 Accepted,23-06-2018 Publish,23-06-2018
}

\begin{abstract}
: the purpose of this research is to know the difference of student physics learning result by using Student Team Achievement Division (STAD) and Teams Games Tournament (TGT) learning model. The type of research used is quantitative research with experimental research method. The population in this study are all students of class VIII SMP Negeri Air Lesing. In this study the entire population used as a sample, so this research is a sample study with class VIII. 1 as experimental class I and VIII. 2 as experimental class II. The data were collected using a test technique consisting of 7 essay questions. The collected data then analyzed using $t$-test is tcount $=2,104$ and ttable $=2,021$. with criteria $t$ count $>$ ttable, then $\mathrm{HO}$ rejected Ha accepted. Thus the hypothesis proposed in this study accepted the truth. Based on the results of research and discussion it can be concluded that there are differences in the results of physics learning using the Student Team Achievement Division (STAD) learning model and Teams Games Tournament (TGT) learning model At SMP Negeri Air Lesing.
\end{abstract}

Keywords: Learning Outcomes, STAD Teams Games Tournament (TGT)

\begin{abstract}
Abstrak : tujuan penelitian ini adalah untuk mengetahui perbedaan hasil belajar fisika siswa dengan menggunakan model pembelajaran Student Team Achievement Division (STAD) dan model pembelajaran Teams Games Tournament (TGT). Jenis penelitian yang digunakan adalah penelitian kuantitatif dengan metode penelitian eksperimen. Populasi dalam penelitian ini semua siswa kelas VIII SMP Negeri Air Lesing . Pada penelitian ini seluruh populasi dijadikan sebagai sampel, sehingga penelitian ini merupakan penelitian sampel dengan kelas VIII. 1 sebagai kelas ekperimen I dan VIII. 2 sebagai kelas eksperimen II. Pengumpulan data dilakukan dengan teknik tes yang terdiri dari 7 soal essay. Data yang terkumpul kemudian dianalisis menggunakan uji-t adalah $t_{\text {hitung }}=2,104$ dan $t_{\text {tabel }}=2,021$. dengan kriteria $t_{\text {hitung }}>t_{\text {tabel }}$, maka $H_{0}$ ditolak $H_{a}$ diterima. Dengan demikian hipotesis yang diajukan dalam penelitian ini diterima kebenarannya. Berdasarkan hasil penelitian dan pembahasannya dapat disimpulkan bahwa Ada perbedaan hasil belajar fisika menggunakan model pembelajaran Student Team Achievement Division (STAD) dan model pembelajaran Teams Games Tournament (TGT) Di SMP Negeri Air Lesing.
\end{abstract}

Kata kunci : Hasil Belajar, STAD Teams Games Tournament (TGT)

\section{PENDAHULUAN}

Upaya pembangunan manusia Indonesia seutuhnya diantaranya dengan berupaya membuat peningkatan kualitas sumber daya manusia yang memiliki kemampuan dalam memanfaatkan dan menguasai ilmu pengetahuan dan teknologi yang berwawasan . Diantara ilmu pengetahuan dan teknologi tersebut salah satunya ialah pendidikan. Peran pendidikan dalam pembangunan yang semakin berkembang saat ini, khusunya di negara Indonesia sangatlah penting karena mempunyai relevansi dalam menghasilkan para pemikir dan tenaga terampil untuk ikut serta mensukseskan pembangunan. Pendidikan yang diselenggarakan di sekolah, keluarga dan masyarakat, diharapkan harus mampu memberikan dampak yang positif dan dapat menjadikan kualitas manusia Indonesia semakin meningkat dan 
menumbuhkan kesadaran bangsa untuk selalu berupaya menambah pengetahuan dan keterampilan serta pengalaman.

Pendidikan merupakan salah satu aspek yang penting dalam meningkatkan kualitas sumber daya manusia dalam menghadapi perkembangan teknologi yang disertai dengan perkembangan Ilmu Pengetahuan Alam (IPA). Perkembangan yang begitu pesat, membuat para pendidik (guru) untuk merancang, mengembangkan, dan melaksanakan pendidikan yang lebih mengarah pada penguasaan konsep IPA yang dapat menunjang dalam kehidupan bermasyarakat. Untuk dapat menyesuaikan perkembangan IPA maka kreativitas sumber daya manusia mutlak harus ditingkatkan (Muslich 2007).

Fisika merupakan salah satu unsur utama dalam pembangunan dan mewujudkan ilmu Pengetahuan dan Teknologi. Setiap negara berlomba-lomba menemukan produk terutama hasil IPTEK. IPTEK tidak lepas dari salah satu unsur pokok yaitu ilmu fisika, yang bermanfaat bagi perkembangan teknologi. Fisika juga menjadi bagian dari pendidikan bagi semua siswa. Dengan demikian fisika mempunyai peranan yang sangat penting.

Berdasarkan observasi yang dilakukan terhadap siswa kelas VIII di SMP Negeri Air Lesing diperoleh bahwa pelajaran IPA sulit karena terlalu banyak hitungan didukung juga dengan hasil belajar siswa yang rendah dan proses pembelajaran yang dilakukan disana masih didominasi dengan menggunakan pembelajaran konvensional. Hal ini dapat dilihat dari nilai semester ganjil dikelas VIII hanya mencapai $45 \%$ siswa yang dapat mencapai nilai KKM 73. Hal tersebut membuktikan bahwa 55\% siswa tersebut belum mencapai nilai KKM, sehingga mereka harus mengikuti remidial. Hal itu menunjukkan bahwa proses pembelajaran yang cenderung terpusat pada guru dan siswa hanya mendengarkan saja, hal ini dapat mengakibatkan siswa cepat jenuh, karena tidak ada keterlibatan siswa secara aktif dalam proses pembelajaran.

Salah satu model pembelajaran yang dapat mengatasi permasalahan tersebut adalah model pembelajaran kooperatif. Model pembelajaran tersebut bisa menjadi strategi dalam mengatasi masalah pendidikan. Menurut Jhonson bahwa tujuan pokok pembelajaran kooperatif adalah memaksimalkan belajar siswa untuk peningkatan prestasi akademik dan pemahaman baik secara individu maupun kelompok (Trianto, 2009). Ada banyak macam pembelajaran kooperatif, beberapa model pembelajaran kooperatif adalah model pembelajaran STAD dan TGT.

Menurut R. Slavin dan temantemannya di universitas John Hopkin (Slavin, 2010) model pembelajaran STAD merupakan salah satu metode pembelajaran kooperatif yang paling sederhana, dan merupakan model yang paling baik untuk pemulaan bagi para guru yang baru menggunakan pendekatan kooperatif. Jadi model pembelajaran kooperatif tipe STAD merupakan metode pembelajaran yang baik untuk pemulaan bagi para guru dan merupakan salah satu metode yang paling sederhana.

Model pembelajaran Student Team Achievement Division (STAD) merupakan model pembelajaran kooperatif yang dikembangkan oleh R. Slavin merupakan salah satu metode pembelajaran kooperatif yang paling sederhana, dan merupakan model yang paling baik untuk pemulaan bagi para guru yang baru menggunakan pendekatan kooperatif (Slavin, 2005).

Menurut Rusman Student Team Achievement Division (STAD) merupakan suatu metode generik tentang pengaturan kelas dan bukan metode pengajaran kompeherensif untuk subjek tertentu, guru menggunakan pelajaran dan materi mereka sendiri (Rusman, 2011). Jadi 
dapat disimpulkan bahwa Student Team Achievement Division (STAD) adalahsuatu metode generik tentang pengaturan kelas dan tidak menggunakan metode pembelajaran kompeherensif untuk subjek tertentu, guru menggunakan pelajaran dan materi mereka sendiri.

Tabel 1. Langkah-Langkah Pembelajaran Kooperatif Tipe STAD

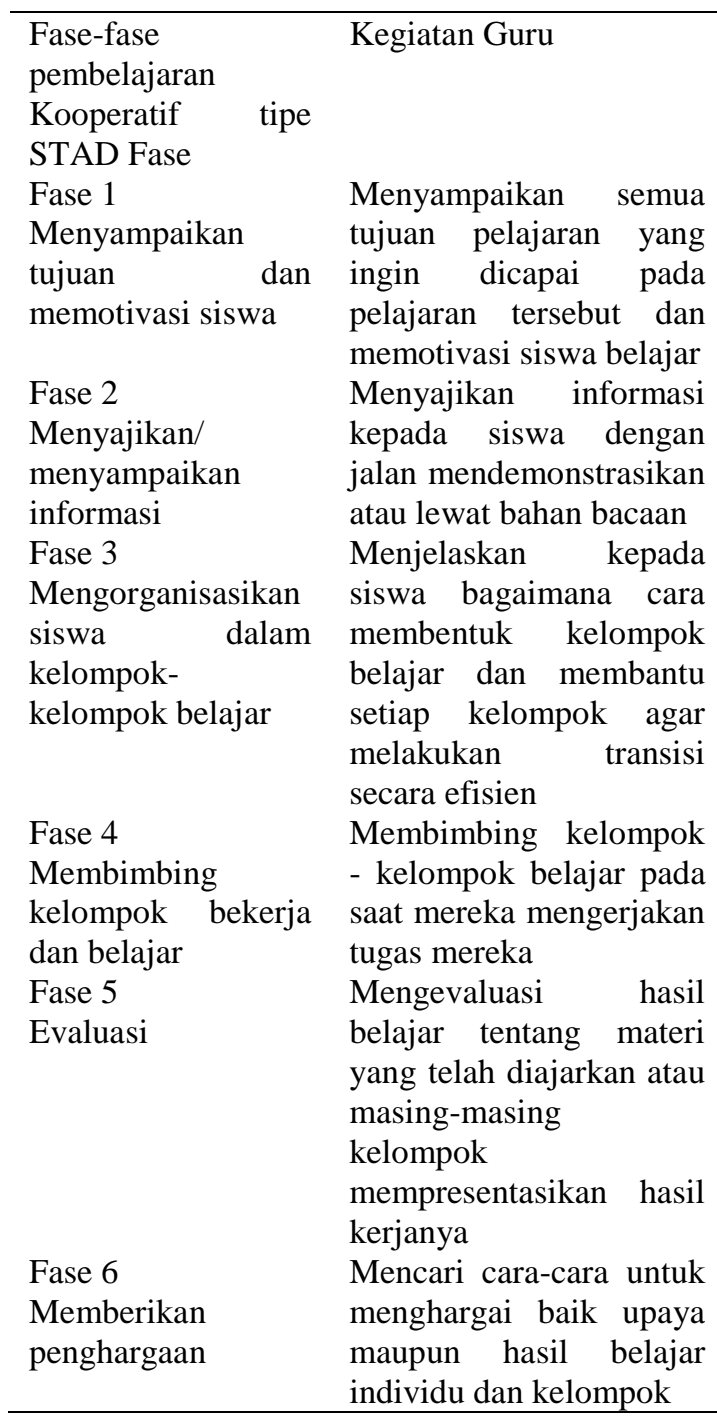

(Trianto, 2007)

Model Pembelajaran Team Games

Tournament (TGT) adalah metode yang dikembangkan oleh DeVries dan Slavin, dengan menugaskan kelompok untuk bekerja atau berdiskusi memahami informasi dan latihan sebelum berkompetensi dengan kelompok lainnya dalam turnamen (Sani, Ridwan Abdullah, 2013). Jadi model pembelajarankooperatif tipe TGT merupakan penugasan kelompok dengan berdiskusi dalam kelompok untuk memperoleh informasi dan latihan sebelum berkompetensi.

Games Tournament (TGT) adalah metode yang dikembangkan oleh DeVries dan Slavin, dengan menugaskan kelompok untuk bekerja atau berdiskusi memahami informasi dan latihan sebelum berkompetensi dengan kelompok lainnya dalam turnamen (Sani, Ridwan Abdullah, 2013).Model pembelajaran TGT memiliki tipe yang hampir sama dengan STAD. Pembelajaran TGT melibatkan aktifitas seluruh peserta didik tanpa harus ada perbedaan status, melibatkan peran peserta didik sebagai tutor teman sebaya, dan mengandung unsur permainan dan penguatan (Reinforcement). Pembealajaran TGT memberi peluang kepada peserta didik untuk belajar lebih rileks disamping menumbuhkan tanggungjawab, kerja sama, persaingan sehat, dan keterlibatan belajar.

Prosedur pelaksanaan pembelajaran TGT secara umum adalah sebagai berikut.

1. Guru memilih topik pembelajaran dan menyajikannya pada peserta didik.

2. Guru mengembangkan daftar pertanyaan, memberi nomor, dan mengguntingnya menjadi potongan kecil.

3. Guru mengelompokkan peserta didik secara heterogen bergantung pada kemampuannya dalam beberapa kelompok.

4. Guru menempatkan peserta didik dalam beberapa kelompok yang baru tersebut memiliki kompetensi yang sama.

5. Peserta didik kemballi kemeja kelompoknya (kelompok awal) dan melaporkan perolehan nilainya

Model pembelajaran kooperatif dapat melibatkan siswa secara aktif diantaranya adalah STAD dan TGT. Dalam model pembelajaran STAD adalah metode pembelajaran kooperatif yang paling sederhana, dan merupakan model 
yang paling baik untuk pemulaan bagi para guru yang baru menggunakan pendekatan kooperatif. Sedangkan model pembelajaran TGT siswa memainkan permainan dengan anggota-anggota tim lain untuk memperoleh skor bagi tim mereka masing-masing .

Berdasarkan uraian latar belakang diatas maka rumusan masalah dalam penelitian ini adalah Apakah ada Perbedaan Hasil Belajar Fisika Menggunakan Model Pembelajaran Studend Team Achievement Division (STAD) dan Model Pembelajaran Teams Games Tournament (TGT) kelas VIII SMP Negeri Air Lesing?

Berdasarkan rumusan masalah di atas, maka tujuan dari penelitian ini adalah untuk mengetahui perbedaan hasil belajar Fisika Menggunakan model pembelajaran kooperatif tipe Student Team Achievement Division (STAD) dan model pembelajaran kooperatif tipe Teams Games Tournament (TGT) di kelas VIII SMP Negeri Air Lesing.

\section{LANDASAN TEORI}

Model pembelajaran Kooperatif Tipe Student Team Achievement Division (STAD)

Menurut Slavin Student Team Achievement Division (STAD) merupakan model pembelajaran kooperatif yang dikembangkan oleh R. Slavin dan temantemannya di universitas John Hopkin. "Model STAD merupakan salah satu metode pembelajaran kooperatif yang paling sederhana, dan merupakan model yang paling baik untuk pemulaan bagi para guru yang baru menggunakan pendekatan kooperatif'(Slavin, 2005).

Menurut Rusman Student Team Achievement Division (STAD) merupakan suatu metode generik tentang pengaturan kelas dan bukan metode pengajaran kompeherensif untuk subjek tertentu, guru menggunakan pelajaran dan materi mereka sendiri (Rusman, 2011).
Model kooperatif tipe STAD ini mudah untuk digunakan bagi para guru pemula karena selain mudah dipahami, model pembelajaran ini terdapat siswa dengan kemampuan tinggi, sedang, rendah. Menurut Slavin (2010) Student Team Achievement Division (STAD) terdiri atas lima komponen utama, yaitu presentasi kelas, tim, kuis, skor kemajuan individual, rekognisi tim.

1. Presentasi kelas. Bahan ajar dalam STAD pertama-tama diperkenalkan dalam presentasi di dalam kelas. Ini merupakan pengajaran langsung seperti yang sering kali dilakukan atau diskusi pelajaran yang dipimpin oleh guru, tetapi bisa juga memasukkan presentasi audiovisual. Bedanya presentasi kelas dengan pengajaran biasa hanyalah bahwa presentasi tersebut haruslah benar-benar berfokus pada unit STAD. Dengan cara ini, para siswa akan menyadari bahwa mereka harus benar-benar memberi perhatian penuh selama presentasi kelas, karena dengan demikian akan sangat membantu mereka mengerjakan kuiskuis, dan skor kuis mereka menentukan skor tim mereka.

2. Tim. Tim terdiri dari empat atau lima siswa yang mewakili seluruh bagian dari kelas dalam hal kinerja akademik, jenis kelamin, ras dan etnisitas. Fungsi utama dari tim ini adalah memastikan bahwa semua anggota tim benar-benar belajar, dan lebih khususnya lagi, adalah untuk mempersiapkan anggotanya untuk bisa mengerjakan kuis dengan baik.

3. Kuis. Setelah satu sampai dua periode presentasi guru dan satu atau dua periode praktik tim, para siswa akan mengerjakan kuis individual. Para siswa tidak diperbolehkan untuk saling membantu dalam mengerjakan kuis. Sehingga, tiap siswa bertanggung jawab secara individual untuk memahami materinya. 
4. Skor kemajuan individual . Skor kemajuan individual adalah untuk memberikan kepada tiap siswa tujuan kinerja yanga akan dapat dicapai apabila mereka bekerja lebih giat dan memberikan kinerja yang lebih baik dari sebelumnya. Tiap siswa dapat memberikan konstribusi poin yang maksimal kepada timnya dalam sistem skor ini, tetapi tak ada siswa yang dapat melakukannya tanpa memberikan usaha mereka yang terbaik.

5. Rekognisi tim. Tim akan mendapatkan sertifikasi atau bentuk penghargaan yang lain apabila skor rata-rata mereka mencapai ktiteria tertentu. Skor tim siswa dapat juga digunakan untuk menentukan dua puluh persen dari peringkat mereka.

6. Pemberian Skor Tim. Skor kemajuan individual adalah untuk memberikan kepada setiap siswa tujuan kinerja yang akan dicapai apabila mereka bekerja lebih giat dan memberikan kinerja yang lebih baik daripada sebelumnya. Tiap siswa dapat memberikan kontribusi poin yang maksimal kepada timnya dalam sistem skor ini, tetapi tak ada siswa yang dapat melakukannya tanpa memberikan usaha mereka yang terbaik.

Berdasarkan penjabaran tentang model kooperatif tipe STAD di atas dapat disimpulkan bahwa tipe STAD merupakan model pembelajaran kooperatif yang mana siswa-siswa dikelompokkan dalam 4-5 anggota berdasarkan tingkat kepandaian, jenis kelamin. Komponen utama dalam STAD adalah presentasi kelas, tim, kuis, skor kemajuan individu, rekognisi tim.

Tabel. 2 Langkah-Langkah Pembelajaran Kooperatif Tipe STAD

\begin{tabular}{lcc}
\hline Fase-fase & & Kegiatan Guru \\
pembelajaran & & \\
Kooperatif & tipe & \\
\hline
\end{tabular}

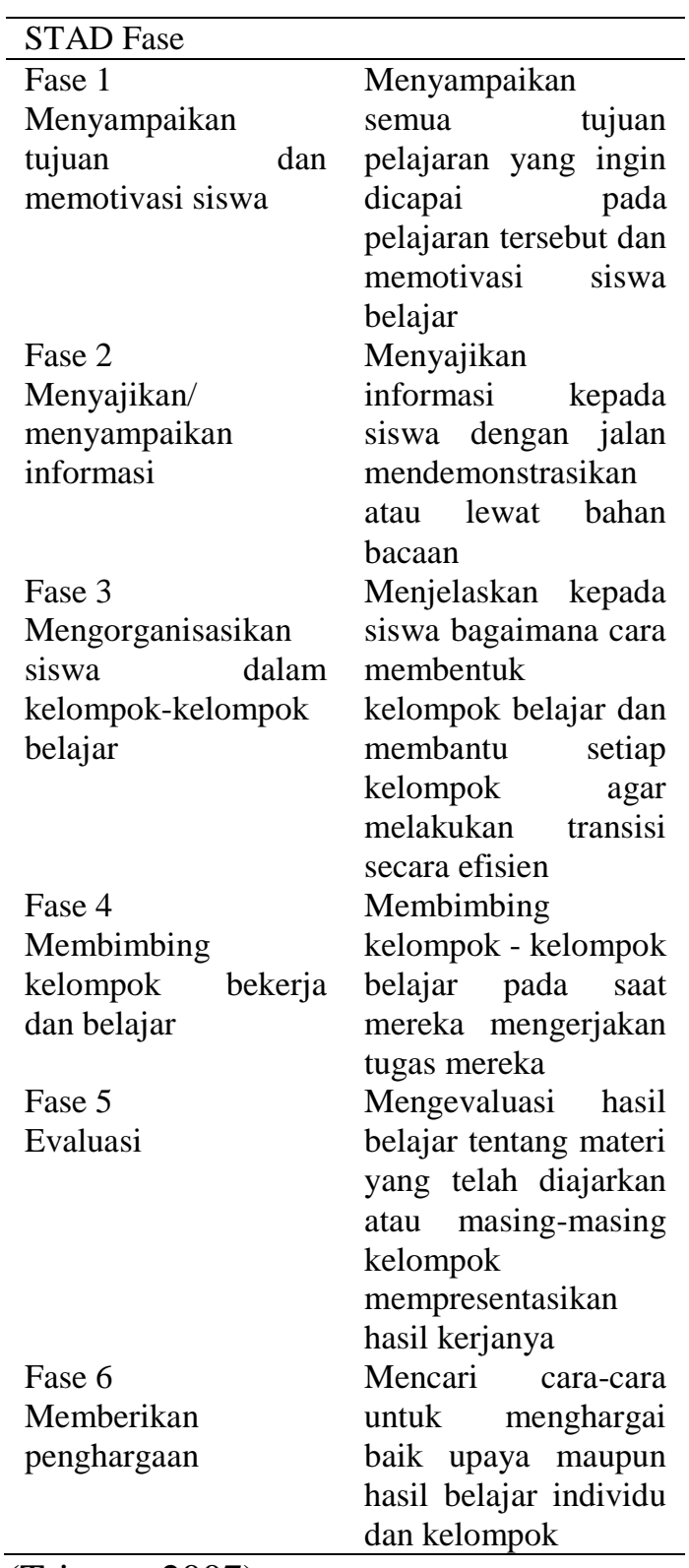

(Trianto, 2007)

\section{Kelebihan dan kekurangan Model pembelajaran kooperatif tipe STAD}

Kelebihan dalam penggunaan model pembelajaran STAD sebagai berikut:

1. Siswa bekerja sama dalam mencapai tujuan dengan menjunjung tinggi norma-norma kelompok.

2. Siswa aktif membantu dan memotivasi semangat untuk berhasil bersama.

3. Aktif berperan sebagai tutor sebaya untuk lebih meningkatkan keberhasilan kelompok. 
4. Interaksi antar siswa seiring dengan peningkatan kemampuan mereka dalam berpendapat.

Kelemahan dalam penggunaan model pembelajaran STAD sebagai berikut:

1. Sejumlah siswa mungkin banyak yang bingung karena belum terbiasa dengan perlakuan seperti ini.

2. Membutuhkan waktu yang lebih lama untuk siswa sehingga sulit mencapai target kurikulum.

3. Membutuhkan waktu yang lebih lama untuk guru sehingga pada umumnya guru tidak mau menggunakan pembelajaran kooperatif tipe STAD.

4. Membutuhkan kemampuan khusus guru sehingga tidak semua guru dapat melakukan pembelajaran kooperatif STAD.

5. Menuntut sifat tertentu dari siswa, misalnya sifat suka bekerja sama

\section{Model Pembelajaran Team Games Tournament (TGT)}

Model Pembelajaran Team Games Tournament (TGT) adalah metode yang dikembangkan oleh DeVries dan Slavin, dengan menugaskan kelompok untuk bekerja atau berdiskusi memahami informasi dan latihan sebelum berkompetensi dengan kelompok lainnya dalam turnamen (Sani, Ridwan Abdullah, 2013).

Model pembelajaran TGT memiliki tipe yang hampir sama dengan STAD. Pembelajaran TGT melibatkan aktifitas seluruh peserta didik tanpa harus ada perbedaan status, melibatkan peran peserta didik sebagai tutor teman sebaya, dan mengandung unsur permainan dan penguatan(Reinforcement). Pembealajaran TGT memberi peluang kepada peserta didik untuk belajar lebih rileks disamping menumbuhkan tanggungjawab, kerja sama, persaingan sehat, dan keterlibatan belajar.

Prosedur pelaksanaan pembelajaran TGT secara umum adalah sebagai berikut.
1. Guru memilih topik pembelajaran dan menyajikannya pada peserta didik.

2. Guru mengembangkan daftar pertanyaan, memberi nomor, dan mengguntingnya menjadi potongan kecil.

3. Guru mengelompokkan peserta didik secara heterogen bergantung pada kemampuannya dalam beberapa kelompok.

4. Guru menempatkan peserta didik dalam beberapa kelompok yang baru tersebut memiliki kompetensi yang sama.

5. Peserta didik kemballi kemeja kelompoknya (kelompok awal) dan melaporkan perolehan nilainya

Kelebihan dan kekurangan model pembelajaran Kooperatif tipe Team Games Tournament (TGT)

Menurut Sani, Ridwan (2013) bahwa kelebihan dan kekurangan model pembelajaran kooperatif tipe TGT adalah sebagai berikut:

Kelebihan model pembelajaran kooperatif tipe TGT

1. Lebih meningkatkan pencurahan waktu untuk tugas.

2. Mengedapnkan perbedaan terhadap perbedaaan inidividu

3. Dengan waktu yang sedikit dapat menguasai materi secara mendalam.

4. Proses belajar mengajar berlasung dari proses keaktifan dari siswa

5. Mendidik siswa untuk berlatih bersosialisi dengan orang lain.

6. Memotivasi peserta didik untuk belajar lebih tinggi.

7. Hasil belajar siswa lebih baik.

8. Meningkatkan kebaikan budi, kepekaan dan toleransi.

Kelemahan model pembelajaran kooperatif tipe TGT

1. Guru sulit mengelompokkan siswayang mempunyai kemampuan heterogendari segi akademis.

2. Masih adnya siswa yang berkemampuan tinggi kurang terbiasa 
dan sulit memberikan penjelasan kepada siswa lainnya.

3. Waktu yang digunakan sangat lama.

\section{Perbandingan Model Pembelajaran Kooperatif Tipe STAD dan Model Pembelajaran Kooperatif Tipe TGT \\ Model pembelajaran kooperatif tipe STAD dan model pembelajaran kooperatif tipe TGT juga memiliki beberapa perbandingan dapat dilihat pada tabel. 3 .}

Tabel. 3. Perbandingan Model Pembelajaran Kooperatif Tipe STAD dan Model Pembelajran Kooperatif Tipe TGT

\begin{tabular}{|c|c|c|}
\hline & STAD & TGT \\
\hline $\begin{array}{l}\text { Tujuan } \\
\text { kognitif }\end{array}$ & $\begin{array}{l}\text { Informasi } \\
\text { akademik } \\
\text { sederhana } \\
\end{array}$ & $\begin{array}{l}\text { Informasi } \\
\text { akademik } \\
\text { sederhana } \\
\end{array}$ \\
\hline $\begin{array}{l}\text { Tujuan } \\
\text { sosial }\end{array}$ & $\begin{array}{l}\text { Kerja } \\
\text { kelompok dan } \\
\text { kerja sama }\end{array}$ & $\begin{array}{l}\text { Kerja kelompok } \\
\text { dan kerja sam }\end{array}$ \\
\hline $\begin{array}{l}\text { Struktur } \\
\text { tim }\end{array}$ & $\begin{array}{l}\text { Kelompok } \\
\text { belajar } \\
\text { heterogen } \\
\text { dengan 4-5 } \\
\text { orang anggota }\end{array}$ & $\begin{array}{l}\text { Kelompok } \\
\text { belajar } \\
\text { heterogen } \\
\text { dengan 5-6 } \\
\text { orang anggota }\end{array}$ \\
\hline $\begin{array}{l}\text { Pemilihan } \\
\text { topic }\end{array}$ & Biasanya guru & Biasanya guru \\
\hline $\begin{array}{l}\text { Tugas } \\
\text { utama }\end{array}$ & $\begin{array}{l}\text { Siswa dapat } \\
\text { menggunakan } \\
\text { lembar } \\
\text { kegiatan dan } \\
\text { saling } \\
\text { membantu } \\
\text { untuk } \\
\text { menuntaskan } \\
\text { materi } \\
\text { belajarnya }\end{array}$ & $\begin{array}{l}\text { Siswa } \\
\text { menyerlesaikan } \\
\text { tugas kelompok }\end{array}$ \\
\hline Penilaian & Tes mingguan & $\begin{array}{l}\text { Bervariasi } \\
\text { dapat berupa tes } \\
\text { mingguan }\end{array}$ \\
\hline Pengakuan & $\begin{array}{l}\text { Lembar } \\
\text { pengetahuan } \\
\text { dan publikasi }\end{array}$ & $\begin{array}{l}\text { Lembar } \\
\text { pengetahuan } \\
\text { dan publikasi }\end{array}$ \\
\hline
\end{tabular}

(Rusman, 2011)

\section{METODE PENELITIAN}

Metode penelitian adalah suatu cara ilmiah yang digunakan untuk mendapatkan data dengan tujuan dan kegunaan tertentu (Sugiyono, 2012). Jenis penelitian yang digunakan adalah penelitian kuantitatif dengan metode penelitian eksperimen.

Berdasarkan tujuan yang ingin dicapai, maka dalam penelitian ini menggunakan pola desain penelitian Pretest- Posttes Control Group Design. Didalam desain ini tes dibagi menjadi dua kelompok eksperimen dan membedakan dua perlakuan antara kelompok eksperimen I dan kelompok eksperimen II.

Dimana kelompok eksperimen I menggunakan model pembelajaran kooperatif tipe STAD dan kelompok eksperimen II menggunakan model pembelajaran kooperatif tipe TGT. Menurut Arikunto (2010) desain penelitian dapat dilihat pada tabel 4

Tabel 4. Rancangan Penelitian

\begin{tabular}{cccc}
\hline Group & $\begin{array}{c}\text { Pre- } \\
\text { test }\end{array}$ & Treatment & $\begin{array}{c}\text { Pos- } \\
\text { test }\end{array}$ \\
$\begin{array}{c}\text { Group } \\
\text { Eksperimen I } \\
\text { Group }\end{array}$ & $o_{1}$ & $X_{1}$ & $o_{2}$ \\
Eksperimen II & $o_{3}$ & $X_{2}$ & $o_{4}$ \\
\hline
\end{tabular}

Keterangan:

$O_{1}=$ tes awal (pre-test) group eksperimen I

$\mathrm{O}_{3}=$ tes awal (pre-test) group eksperimen II

$\mathrm{O}_{2}=$ tes akhir (pos-test) group eksperimen I

$\mathrm{O}_{4}=$ tes akhir (pos-test) group eksperimen II

$X_{1}=$ pembelajaran dengan Student Team Achievement Division (STAD)

$X_{2}=$ pembelajaran dengan model Teams Games Tournament (TGT)

Adapuntahapan-tahapanpelaksanaan penelitian ini adalah sebagai berikut:

1. Melaksanakan pre-test pada kelas eksperimen I dan kelas ekspperimen II untuk mengetahui hasil belajar awal siswa sebelum diberi perlakuan. 
2. Melakukan analisa data pretest yaitu uji normalitas, uji homogenitas, dan uji z pada kelas eksperimen I dan kelas eksperimen II

3. Pemberian perlakuan dengan menggunakan model Problem Based Instruction di kelas eksperimen I dan pemberian perlakuan dengan menggunakan model pembelajaran inquiry di kelas eksperimen II.

4. Melakukan post-testuntuk mengetahui kemampuan akhir siswa setelah diberi perlakuan pada kelas eksperimen 1 dan kelas eksperimen 2.

5. Melakukan analisis data post-test yaitu uji normalitas, uji homogenitas, uji $\mathrm{z}$ pada kelas eksperimen I dan kelas eksperimen II. Dari uji hipotesis ini diketahui ada atau tidaknya perbedaan model pembelajaran Problem Based Instruction dan model pembelajaran inquiry.

Uji hipotesis (Uji kesamaan dua rata-rata) dilakukan jika data berdistribusi normal dan homogen. Uji kesamaan dua rata-rata digunakan untuk mengetahui ada tidak adanya perbedaan hasil belajar setelah diberi perlakuan antara dua buah data.

$\mathrm{H}_{0}: \mu_{1} \leq \mu_{2}$ : Hipotesis nol atau pembanding, rata-rata hasil belajar fisika setelah mengikuti model pembelajaran Student Team Achieviment Division kurang dari atau sama dengan model pembelajaran Teams Games Tournament.

$\mathrm{H}_{\mathrm{a}}: \mu_{1}>\mu_{2}:$ Hipotesis alternatif atau kerja, rata-rata hasil belajar fisika dengan model pembelajaran Student Team Achieviment Division signifikan lebih dari rata-rata hasil belajar model pembelajaran Teams Games Tournament.

Menurut Sudjana (2005:239) jika kedua data berdistribusi normal dan homogen, maka uji statistik yang digunakan untuk menguji hipotesis di atas adalah menggunakan uji $\mathrm{t}$ dengan rumus:

$$
t=\frac{\overline{x_{1}}-\overline{x_{2}}}{s \sqrt{\frac{1}{n_{1}}+\frac{1}{n_{2}}}} \text { dengan, }
$$

$s^{2}=\frac{\left(n_{1}-1\right) s_{1}^{2}+\left(n_{2}-1\right) s_{2}^{2}}{n_{1}+n_{2}-2}($ Sudjana, 2005)

Keterangan :

$\overline{x_{1}}=$ Skor rata-rata kelompok

eksperimen I

$\overline{x_{2}}=$ Skor rata-rata kelompok eksperimen II

$\mathrm{n}_{1}=$ Jumlah siswa kelompok eksperimen I

$\mathrm{n}_{2}=$ Jumlah siswa kelompok eksperimen II

$s_{1} \quad=$ Simpangan baku kelompok eksperimen I

$s_{2} \quad=$ Simpangan baku kelompok eksperimen II

Hasil $t_{\text {hitung }}$ yang diperoleh selanjutnya dibandingkan dengan $t_{\text {tabel. }}$ Kriteria pengujian hipotesis adalah $\mathrm{H}_{0}$ diterima jika $\mathrm{t}_{\text {hitung }} \leq \mathrm{t}_{\text {tabel }}$, dan $\mathrm{H}_{0}$ ditolak jika $\mathrm{t}_{\text {hitung }}$ $>\mathrm{t}_{\text {tabel }}$, dengan $\mathrm{dk}=\left(n_{1}+n_{2}-2\right)$ pada taraf signifikan 5\%.

\section{HASIL DAN PEMBAHASAN}

Hasil penelitian ini memperoleh nilai rata-rata pre-test kelas eksperimen I sebesar 15,36 dan kelas eksperimen II sebesar 18,2. Setelah diberi perlakuan yang berbeda diperoleh rata-rata nilai post-test kelas ekperimen I sebesar 78,7 dan kelas eksperimen II sebesar 73. Hal ini menunjukkan hasil post-test kelas eksperimen I lebih besar dibandingkan dengan kelas eksperimen IIsehingga dapat disimpulkan bahwa perbedaan hasil belajar fisika dengan menggunakan Student Team Achieviment Division

Sebagai model eksperimen I lebih baik dibandingkan dengan menggunakan model pembelajaran Team Games Tournamentsebagai model eksperimen II terhadap hasil belajar siswa kelas VIII 


\section{Analisis Data}

Hasil analisis data pre-test dan posttest kelas eksperimen I dan kelas eksperimen II dapat dilihat dalam tabel 5 dan tabel 6 berikut:

Tabel 5. Rekapitulasi Data Nilai Pre-test Kelas Eksperimen I dan Pre-test Kelas Eksperimen II

\begin{tabular}{|c|c|c|c|c|c|c|}
\hline $\mathbf{D}$ & $\mathbf{a}$ & $\mathbf{t}$ & Varians & $\overline{F_{\text {hitung }}}$ & $\overline{F_{\text {tabel }}}$ & Kesimpulan \\
\hline \multicolumn{3}{|c|}{ Pre-test Kelas EksperimenI } & 35,24 & 1,33 & 2,83 & Homogen \\
\hline \multicolumn{3}{|c|}{ Pre-test Kelas Eksperimen II } & 34,64 & & & \\
\hline \multicolumn{3}{|c|}{ Post-test Kelas EksperimenI } & 158,05 & 1,51 & 2,83 & Homogen \\
\hline \multicolumn{3}{|c|}{ Post-test Kelas Eksperimen II } & 104,16 & & & \\
\hline
\end{tabular}

Tabel 6. Rekapitulasi Data Nilai Post-test Kelas Eksperimen dan Post-test Kelas Eksperimen II

\begin{tabular}{|c|c|c|c|c|c|c|}
\hline $\bar{D}$ & $\overline{\mathbf{a}}$ & $\overline{\mathbf{a}}$ & Varians & $\mathbf{F}_{\text {hitung }}$ & $\overline{F_{\text {tabel }}}$ & Kesimpulan \\
\hline \multicolumn{3}{|c|}{ Pre-test Kelas EksperimenI } & 35,24 & 1,33 & 2,83 & Homogen \\
\hline \multicolumn{3}{|c|}{ Pre-test Kelas Eksperimen II } & 34,64 & & & \\
\hline \multicolumn{3}{|c|}{ Post-test Kelas EksperimenI } & 158,05 & 1,51 & 2,83 & Homogen \\
\hline \multicolumn{3}{|c|}{ Poss-test Kelas Eksperimen II } & 104,16 & & & \\
\hline
\end{tabular}

Uji Normalitas DataPre-test dan Posttest

Hasil uji normalitas data pre-test dan post-test kelas eksperimen I dan kelas eksperimen IIdinyatakan dalam tabel 5 berikut:

Tabel 7. Rekapitulasi Hasil Uji Normalitas Data Pretest danpost-testKelas Eksperimen I dan Kelas Eksperimen II

\begin{tabular}{|c|c|c|c|c|c|}
\hline Kelas & Tes & $\chi_{\text {hitung }}^{2}$ & $\mathrm{dk}$ & $\chi_{\text {tabel }}^{2}$ & $\begin{array}{l}\text { Kesimp } \\
\text { ulan }\end{array}$ \\
\hline $\begin{array}{l}\text { Ekperi } \\
\text { men } 1\end{array}$ & $\begin{array}{ll}\text { 1. } & \text { Tes } \\
& \text { awal } \\
\text { 2. } & \text { Tes } \\
& \text { akhi } \\
\text { r }\end{array}$ & $\begin{array}{l}6,566 \\
5,138\end{array}$ & $\begin{array}{l}6 \\
6\end{array}$ & $\begin{array}{l}11,07 \\
11,07\end{array}$ & $\begin{array}{l}\text { Normal } \\
\text { Normal }\end{array}$ \\
\hline $\begin{array}{l}\text { Ekperi } \\
\text { men } 2\end{array}$ & $\begin{array}{ll}\text { 1. } & \text { Tes } \\
\text { awal } \\
\text { 2. }\end{array} \begin{array}{l}\text { Tes } \\
\text { akhi } \\
\mathrm{r}\end{array}$ & $\begin{array}{l}6,711 \\
1,911\end{array}$ & $\begin{array}{l}6 \\
6\end{array}$ & $\begin{array}{l}11,07 \\
11,07\end{array}$ & $\begin{array}{l}\text { Normal } \\
\text { Normal }\end{array}$ \\
\hline
\end{tabular}

\section{Uji Homogenitas Data Pre-test dan}

Post-test

Uji homogenitas pre-test dan posttest kelas eksperimen I dan kelas eksperimen II menggunakan uji F. Untuk selengkapnya perhitungan uji homogenitas tersebut tertera pada tabel 6 dibawah ini.

Tabel 8. Rekapitulasi Hasil Uji Homogenitas Data Pre-test dan Post-test Kelas Eksperimen I dan Kelas Eksperimen II

\begin{tabular}{|c|c|c|c|c|c|}
\hline \multicolumn{3}{|c|}{ Kelas EksperimenI } & \multicolumn{3}{|c|}{ Kelas Eksperimen II } \\
\hline Rentang Nilai & $\mathrm{F}$ & Rata-atata & Rentang Nilai & $\mathrm{F}$ & Rata-rata \\
\hline $6-9$ & 5 & \multirow{7}{*}{15,36} & $9-12$ & 4 & \multirow{7}{*}{18,2} \\
\hline $10-13$ & 3 & & $13-16$ & 3 & \\
\hline 14-17 & 8 & & $17-20$ & 8 & \\
\hline 18-21 & 3 & & $21-24$ & 2 & \\
\hline $22-25$ & 2 & & $25-28$ & 2 & \\
\hline \multirow[t]{2}{*}{ 26-29 } & 2 & & $29-32$ & 1 & \\
\hline & 23 & & Jumlah & 20 & \\
\hline \multicolumn{3}{|c|}{ Kelas EksperimenI } & \multicolumn{3}{|c|}{ Kelas Eksperimen II } \\
\hline Rentang Nilai & $\mathrm{F}$ & Rata-rata & Rentang Nilai & Fotweni & Rata-ratata \\
\hline $50-58$ & 4 & 78,7 & $52-59$ & 1 & 73 \\
\hline $59-67$ & 2 & & $60-67$ & 2 & \\
\hline 68-76 & 8 & & $68-75$ & 7 & \\
\hline $77-85$ & 5 & & $76-83$ & 5 & \\
\hline 86-94 & 3 & & $84-91$ & 3 & \\
\hline 95-104 & 1 & & $92-99$ & 2 & \\
\hline
\end{tabular}

Berdasarkan Tabel 8 di atas dapat disimpulkan bahwa data penelitian tersebut berdistribusi normal dan homogen, maka telah memenuhi persyaratan untuk dilakukan pengujian hipotesis.

\section{Pengujian Hipotesis Kemampuan Pre- test \\ Hasil pemberian pre-test kepada} kelas eksperimen I dan kelas eksperimen II diperoleh rata-rata untuk kelas eksperimen I adalah 15,36 dan untuk kelas eksperimen II adalah18,2. Dari perhitungan analisis data diperoleh $t_{\text {hitung }}$ $1,672<t_{\text {tabel }}$ 2,021. Maka dapat disimpulkan ada kesamaan kemampuan awal siswa. Untuk lebih jelasnya dapat dilihat pada Tabel 7 di bawah ini. 
Tabel 9. Rekapitulasi Perhitungan Uji Hipotesis Kemampuan Pre-test Kelas Ekspeimen I dan Eksperimen II

\begin{tabular}{lllll}
\hline Data kelas & $\begin{array}{l}\text { Rata- } \\
\text { rata }\end{array}$ & $\mathrm{t}_{\text {hitung }}$ & $\mathrm{t}_{\text {tabel }}$ & Kesimpulan \\
$\begin{array}{l}\text { Eksperimen } \\
15,36\end{array}$ & 1,671 & 2,02 & $\mathrm{H}_{0}$ diterima \\
$\begin{array}{l}\text { Ekeperimen } \\
2\end{array}$ & 18,20 & & & \\
\hline
\end{tabular}

Berdasarkan Tabel 9 di atas, perhitungan uji perbedaan nilai rata-rata pre-tes kelas eksperimen I dan kelas eksperimen II untuk $\alpha=0,05$, dapat disimpulkan bahwa kemampuan awal siswa pada kelas eksperimen I sama ekperimen I 78,7 dan kelas eksperimen II73. Hal ini menunjukkan hasil post-test kelas eksperimen I lebih besar dibandingkan dengan kelas eksperimen II

\section{Pengujian Hipotesis Kemampuan Post- test}

Setelah diberi perlakuan yang berbeda diperoleh rata-rata post-test kelas ekperimen I 78,7 dan kelas eksperimen II 73. Hal ini menunjukkan hasil post-test kelas eksperimen I lebih besar dibandingkan dengan kelas eksperimen II dengan perbedaan peningkatan sebesar 18,88 dan $t_{\text {hitung }}>t_{\text {tabel }}(2,104>2,021)$

Tabel 10. Rekapitulasi Perhitungan Uji Hipotesis Kemampuan Post-test Kelas Ekspeimen I dan Eksperimen IIdengan kemampuan siswa pada kelas eksperimen II.

\begin{tabular}{lllll}
\hline Data kelas & $\begin{array}{l}\text { Rata- } \\
\text { rata }\end{array}$ & $\mathrm{Z}_{\text {hitung }}$ & $\mathrm{t}_{\text {tabel }}$ & Kesimpulan \\
Eksperimen & 78,7 & 2,104 & 2,02 & $\mathrm{H}_{\mathrm{a}}$ diterima \\
1 & & & & \\
Ekeperimen & 73,0 & & & \\
2 & & & & \\
\hline
\end{tabular}

Permasalahan yang dibahas dalam penelitian ini adalah "adakah perbedaan hasil belajar fisika siswa kelas VIII SMP dengan menggunakan model pembelajaran student team achieviment division dan team games tournament di SMP Negeri Air Lesing tahun pelajaran 2013/2014?". Hasil belajar fisika siswa yang diteliti dalam penelitian ini hanya dari segi kognitif nya dengan soal dalam bentuk essay yang terdiri dari 7soal pertanyaan untuk mengukur kemampuan pengetahuan dalam belajar.

Kelas eksperimen I yaitu kelas VIII. 1 menggunakan model Student Team Achieviment Division (STAD). Model Student Team Achieviment Division (STAD) adalah model pembelajaran yang generik tentang pengaturan kelas dan bukan model pengajaran kompeherensif untuk subjek tertentu, guru menggunakan pelajaran dan materi mereka sendiri (Rusman, 2011).

Model Student Team Achieviment Division (STAD) adalah model pembelajaran yang generik tentang pengaturan kelas dan bukan model pengajaran kompeherensif untuk subjek tertentu, guru menggunakan pelajaran dan materi mereka sendiri (Rusman, 2011).

Model Student Team Achieviment Division (STAD) merupakan pembelajaran yang menuntut siswa untuk melakukan kegiatan pembelajaran lebih bermakna, mengajar bukan transformasi pengetahuan dari guru kepada siswa akan tetapi lebih ditekankan pada upaya memfasilitasi siswa. Pada saat diberi perlakuan dengan materi getaran dan gelombang tidak semua siswa mengikuti pembelajaran dengan model Student Team Achieviment Division (STAD) hanya 3 kelompok siswa saja yang mulai menerapkan pembelajaran ini, salah satunya menerapkan komponen Student Team Achieviment Division (STAD) yaitu bertanya, bekerja sama dan menjawab. Kelompok siswa yang lain hanya menerapkan komponen Student Team Achieviment Division (STAD) bertanya saja karena siswa masih bingung dan kaku menggunakan model Student Team Achieviment Division (STAD). Padahal siswa telah diberi arahan tentang model pembelajaran yang digunakan.

Langkah pembelajaran Kelas eksperimen I menggunakan model pembelajaran student team archieviment division guru mempersentasikan materi 
yang akan didiskusikan. Setelah guru mempersentasikan materi yang akan didiskusikan, siswa dibagi menjadi beberapa kelompok tim. Semua anggota tim benar-benar belajar khususnya lagi untuk mempersiapkan anggotanya untuk mengerjakan kuis dengan baik.

Setelah guru memberikan persentasi kepada siswa, kemudian guru membagikan kuis yang akan dibahas oleh masing-masing kelompok. Setiap kelompok menjawab soal kuis yang diberikan oleh guru. Dengan cara demikian, setiap peserta didik memeliki peluang sukses sesuai dengan tingkat kemampuannya. Tim yang menunjukkan kinerja yang paling baik akan mendapatkan penghargaan. Seperti layaknya lomba, tim yang banyak mengumpulkan poin/skor akan mendapat predikat juara, berurutan sesuai dengan jumlah poin/skor yang berhasil diraihnya.

Penerapan dalam pembelajarannya membutuhkan kesiapan baik dari guru maupun siswa, karena siswa dituntut untuk kritis sedangkan guru dituntut untuk lebih kreatif, sehingga membutuhkan kesiapan yang lebih. Pada kelas eksperimen I setelah menggunakan model Student Team Achieviment Division (STAD) pembelajaran lebih bermakna karena siswa secara langsung akan menghubungkan antara ilmu yang dipelajari dengan kehiduapan sehari-hari.

Selain mempunyai kelebihan proses pembelajaran dengan model Student Team Achieviment Division (STAD) juga mengalami kendala yaitu siswa yang memiliki tingkt pemahaman rendah sulit untuk mengikuti pembelajaran ini dan sulit dalam menyelesaikan pemecahan masalah dalam materi getaran dan gelombang.

Pada kelas eksperimen II menggunakan model pembelajaran teams games tornament dengan menggunakan kartu-kartu yang terdiri dari kartu pertanyaan dan kartu jawaban. Setelah diberi penjelasan mengenai materi, siswa dibagi menjadi beberapa kelompok, masing-masing kelompok diberi tugas untuk belajar bersama agar semua anggoata kelompok memahami materi pelajaran. Setelah itu guru menyiapkan beberapa meja turnamen.

Setiap meja diisi oleh tiga peserta didik yang memiliki kemampuan sama dari kelompok yang berbeda (peserta didik yang pandai berkompetisi dengan peserta didik pandai dari kelompok lainnya, demikian pula peserta didik yang kurang pandai juga berkompetisi dengan peserta didik yang kurang pandai dari kelompok lainnya). Dengan cara demikian , setiap peserta didik memiliki peluang sukses sesuai dengan tingkat kemampuannya. Tim yang menunjukkan kinerja yang paling baik akan mendapatkan penghargaan. Seperti layaknya lomba, tim yang banyak mengumpulkan poin/skor akan mendapat prediakt juara, berurutan sesuai dengan jumlah poin/skor yang berhasil diraihnya.

$$
\text { Setelah kedua kelompok }
$$
mendapat perlakuan yang berbeda, selanjutnya siswa diberi postest dengan soal yang sama. Evaluasi dimaksudkan untuk mengetahui kemampuan pemahaman siswa dari masing-masing kelas. Setelah diberikan perlakuan postest diberikan dalam bentuk tes tertulis yang berupa soal essai.

Berdasarkan hasil analisis data postest terdapat perbedaan hasil belajar antara kelas eksperimen I dan kelas eksperimen II. Hal ini disebabkan perbedaan perlakuan yang diberikan pada kelas eksperimen I dan kelas eksperimen II. Setelah kelas eksperimen I diberikan perlakuan dengan menerapkan model pembelajaran Student Team achieviment Division (STAD) diperoleh nilai rata-rata tes akhir sebesar 78,7 dan simpangan baku sebesar 12,57. Sementara itu kelas eksperimen II setelah diberi perlakuan dengan model Team Games Tournament (TGT) diperoleh nilai rata-rata tes akhir sebesar 73 dan simpangan baku 10,20. 
Dengan demikian rata-rata hasil post-test kelas eksperimen I lebih tinggidari pada rata-rata hasil post-test kelas eksperimen II.

Terdapat perbedaan yang signifikan hasil belajar fisika antara model pembelajaran Student Team Achieviment Division (STAD) dengan Model Team Games Tournament (TGT) dikelas VIII SMP Negeri Air Lesing. Dengan melihat hasil uji hipotesis dengan menggunakan uji t diperoleh bahwa rata-rata nilai kelas eksperimen I tidak sama dengan kelas eksperimen II. Kelas eksperimen I menggunakan model Student Team Achiviment Division (STAD) dan kelas eksperimen II menggunakan model Team Games Tournament (TGT). Hal ini terjadi karena proses kegiatan pembelajaran berbeda baik dari langkah-langkah maupun cara siswa menerima apa yang disampaikan guru.

Secara umum hasil belajar siswa kelas eksperimen I lebih besar dari kelas eksperimen II dikarenakan dikelas eskperimen I yang diajar menggunakan model pembelajaran student teams achieviment division, karena student team achieviment division membuat siswa aktif dan dapat bekerja sama dalam kelompok yang baik. Sehingga seluruh siswa mendapat penjelasan mengenai materi yang dipelajari langsung oleh guru, kemudian siswa ditantang untuk kompetisi dengan siswa lain dalam tim, dimana pemenangnya memperoleh penghargaan.

Adanya kompetisi dan pemberian penghargaan membuat siswa semakin serius dalam pembelajaran dengan model student team archieviment division. Pada model pembelajaran teams games tournament setiap kelompok diberi tugas untuk belajar bersama-sama tentang materi yang akan dibahas. Setelah itu setiap kelompok berada didalam meja turnament yang berisi siswa-siswa yang pintar maupun yang kurang pintar.
Model pembelajaran kooperatif dapat melibatkan siswa secara aktif diantaranya adalah STAD dan TGT. Dalam model pembelajaran STAD adalah metode pembelajaran kooperatif yang paling sederhana, dan merupakan model yang paling baik untuk pemulaan bagi para guru yang baru menggunakan pendekatan kooperatif. Sedangkan model pembelajaran TGT siswa memainkan permainan dengan anggota-anggota tim lain untuk memperoleh skor bagi tim mereka masing-masing.

\section{SIMPULAN}

Berdasarkan data hasil penelitian dan pembahasan dapat disimpulkan bahwa ada pengaruh yang signifikan penggunaan model pembelajaran student team achieviment division (STAD) dengan team games tournament terhadap hasil belajar Fisika siswa pada materi gelombang dikelas VIII di SMP Negeri Air Lesing.Nilai rata-rata post-test siswa kelas eksperimen I yaitu sebesar 78,7 lebih besar dari nilai rata-rata post-test siswa kelas eksperimen II sebesar 73.

\section{DAFTAR PUSTAKA}

Arikunto, S. (2010). Prosedur Penelitian Suatu Pendekatan Praktik. Jakarta: Rineka Cipta.

Muslich, M. (2007). Pembelajaran Berbasis Kompetensi dan Kontektual. Jakarta: Bumi aksara

Robert, E Slavin. (2005). Cooperative Learning: Theory, research, and practice (N.Yusron.Terjemahan). London : Allymand Bacon

Robert, E Slavin. (2010). Cooperative Learning Teori, Riset dan Praktik. Bandung: Nusa Media

Rusman. (2011). Seri Manajemen Sekolah Bermutu. Model-Model Pembelajaran. Mengembangkan Propesionalisme Guru. Jakarta: Rajawali Pers. 
Sani, Ridwan Abdullah. (2013). Inovasi

Pembelajaran. Jakarta: Bumi

Aksara.

Sudjana. (2005). Metoda statistika.

Bandung: Tarsito.

Sugiyono. (2012). Metode Penelitian

Kuantitatif Kualitatif dan $R \& D$.

Bandung: ALFABETA.

Trianto. (2007). Model -model Pembelajaran Inovatif Berorientasi

Kontruktivisme. Jakarta: Prestasi Pustaka Publisher

Trianto. (2009). Mendesain Model Pembelajaran Inovatif-Progresif. Jakarta: Kencana Prenada Media Group. 